\title{
UJI AKTIVITAS ANTIBAKTERI EKSTRAK CATHECHIN TEH PUTIH TERHADAP STREPTOCOCCUS SANGUINIS
}

Muhamad Zakki*

Keywords:
Antibacterial, White tea
cathechin extract,
S. sanguinis

\begin{abstract}
Background: Streptococcus sanguinis is known as an early agent of formation of bacterial plaque. White tea is one of plant with various biological activities that are beneficial to human health.
\end{abstract}

Objective: to examine the antibacterial activity of white tea cathechin extract against bacteria $\mathrm{S}$. sanguinis.

Methods: test material was white tea cathechin extract. In vitro tests were conducted to obtain minimal inhibitory concentration (MIC) and minimal bactericidal concentration (MBC).

Result: The MIC of White tea cathechin extract was 500ppm $(0,5 \mathrm{mg} / \mathrm{ml})$ and MBC was 2000ppm $(2 \mathrm{mg} / \mathrm{ml})$.

Conclusion: White tea cathechin extract has antibacterial properties. White tea cathechin extract can be used as herbal moutwash to control dental plaque.

\section{PENDAHULUAN}

Masalah utama dalam rongga mulut sampai saat ini adalah karies gigi. Riset kesehatan dasar (Riskesdas) tahun 2013 dari Departemen Kesehatan Republik Indonesia menunjukkan bahwa penduduk Indonesia memiliki rata-rata pengalaman karies sebesar 4,6. Karies gigi adalah penyakit infeksi dan merupakan suatu proses demineralisasi yang progresif pada jaringan keras permukaan mahkota dan akar gigi yang dapat dicegah. ${ }^{1}$

Plak memegang peranan penting menyebabkan karies. Plak adalah kumpulan bakteri yang berkembang biak dalam suatu matriks dan melekat erat pada permukaan gigi bila seseorang mengabaikan kebersihan mulutnya. Pembentukan plak diawali dengan adanya pelikel pada permukaan email gigi. Bakteri pertama yang berkontak dengan pelikel adalah Streptococcus sanguinis sebagai inducer dalam proses pembentukan plak gigi. ${ }^{2,3,4}$
Streptococcus sanguinis adalah bakteri Gram positif dan bersifat anaerob fakultatif. Streptococcus sanguinis berikatan langsung pada pelikel permukaan gigi dengan pelbagai mekanisme, salah satunya dengan cara berikatan pada protein saliva seperti prolinerich. Bakteri ini memfasilitasi bakteri lain untuk berkoloni pada permukaan gigi untuk membentuk plak dan berkontribusi terhadap perkembangan karies. ${ }^{5}$

Pembentukan plak dapat dihambat yaitu dengan mengurangi perlekatan, proliferasi dan agregasi bakteri, dapat secara mekanis, kimiawi atau kombinasi keduanya. Tindakan mekanis antara lain dapat dengan menyikat gigi, akan tetapi terkadang hal itu tidak cukup. Tindakan secara kimiawi dapat dilakukan dengan pemberian obat kumur. ${ }^{6}$

Obat kumur khlorheksidin merupakan obat kumur standar emas yang efektif untuk menghambat dan membunuh bakteri Gram positif dan Gram negatif. Khlorheksidin selain mempunyai kemampuan yang efektif untuk

*Program Studi Kedokteran Gigi Fakultas Kedokteran Universitas YARSI

Korespondensi: muhamad.zakki@yarsi.ac.id 
membunuh bakteri juga mempunyai efek samping seperti pewarnaan gigi dan lidah, iritasi mukosa, perubahan rasa kecap dan peningkatan pembentukan kalkulus. ${ }^{7}$

Obat kumur berbahan dasar herbal mulai banyak dikembangkan dengan tujuan untuk mencari bahan alternatif yang efektif dalam mengendalikan bakteri penyebab plak gigi tetapi tidak mempunyai efek samping. ${ }^{7,8}$ Bahan herbal yang banyak tersedia dan dapat digunakan adalah teh. Teh putih adalah salah satu jenis teh yang dipetik dari pucuk teh (peko) yang belum benar-benar mekar dan dibuat hanya dengan dua tahap, yakni pelayuan alami dan pengeringan. 9,10,11 Teh putih merupakan teh terbaik diantara semua jenis teh dikarenakan minimnya proses pembuatannya sehingga kandungan alaminya masih terjaga..$^{10,11}$

Teh mempunyai enam kandungan cathechin yaitu, cathechin, gallocathechin, epicathechin, epigallocathechin, epicathechin gallate dan epigallocathechin gallate. ${ }^{11,12}$ Teh putih mempunyai kandungan Cathechin yang paling tinggi jika dibandingkan dengan jenis teh yang lain. ${ }^{10,11}$ Cathechin merupakan senyawa fenol yang memiliki efek antibakteri. ${ }^{13,14,15}$ Fenol dapat bersifat bakterisidal atau bakteriostatik tergantung pada konsentrasi yang digunakan. ${ }^{13}$

Penelitian ini bertujuan menguji aktivitas antibakteri ekstrak cathechin teh putih terhadap Streptococcus sanguinis. Diharapkan penelitian ini dapat membantu pengembangan dan pemanfaatan teh putih sebagai bahan herbal alternatif yang dapat meningkatkan kesehatan gigi dan mulut.

\section{METODE PENELITIAN}

Penelitian ini menggunakan desain eksperimen laboratorium. Penelitian dilakukan di Laboratorium Kimia FMIPA Universitas Padjadjaran Bandung pada bulan Juni
2014. Pengujian aktivitas antibakteri ekstrak cathechin teh putih dilakukan dengan melihat Konsentrasi Hambat Minimal (KHM) dan Konsentrasi Bunuh Minimal (KBM) terhadap S. sanguinis. Sampel penelitian ini adalah ekstrak cathechin yang diperoleh dari hasil ekstraksi daun teh putih yang diperoleh dari pusat penelitian teh dan kina Gambung dengan menggunakan etanol 96\%. Bakteri uji menggunakan bakteri strain ATCC 10556 S. sanguinis yang diremajakan terlebih dahulu dari biakan induk. Bakteri diremajakan dengan menumbuhkan bakteri pada media Muller Hinton $(\mathrm{MH})$ cair yang diinkubasi selama 48 jam pada suhu $37^{\circ} \mathrm{C}$. Suspensi bakteri uji distandarisasi dengan larutan McFarland 0,5 sehingga jumlah kepadatan bakteri yang digunakan sama yaitu 1,5 x $108 \mathrm{CFU} / \mathrm{ml}$. KHM ekstrak cathechin teh putih ditentukan dengan metode mikrodilusi menggunakan microplate yang terdiri dari 96 sumur.

Larutan ekstrak cathecin dengan konsentrasi awal $8 \mathrm{mg} / \mathrm{ml}, 4 \mathrm{ml}$ akuades dicampur dengan $32 \mathrm{mg}$ ekstrak cathecin sehingga diperoleh $4 \mathrm{ml}$ larutan cathecin dengan konsentrasi 8 $\mathrm{mg} / \mathrm{ml}$ (8000 ppm). Selanjutnya disediakan microplate steril dengan 96 sumur ( 8 baris dan 12 kolom), setiap sumur diisi dengan $150 \mu \mathrm{l}$ Muller Hinton $(\mathrm{MH})$ cair steril sebagai media. Kemudian diambil ekstrak cathechin dengan konsentrasi 8000 ppm sebanyal $150 \mu$ dan dimasukkan kedalam sumur pertama pada baris 1, 2, 5, 6 dan dilakukan pengenceran seri, hasil pengenceran sebesar 4000; 2000; 1000; 500; 250; 125; 62,5; 31,25; 15,63; 7,813; 3,906; 1,953 ppm. Kemudian pada semua sumur baris 5,6,7,8 dimasukkan suspensi bakteri $\mathrm{S}$. sanguinis masing-masing sebanyak $10 \mu \mathrm{l}$. Baris 1 dan 2 (grup 1) berisi media dan sampel $(\mathrm{M}+\mathrm{S})$, baris 3 dan 4 (grup 2) hanya berisi media (M), baris 5 dan 6 (grup 3 ) berisi 
media, sampel dan bakteri $(\mathrm{M}+\mathrm{S}+\mathrm{B})$ yang berfungsi sebagai grup uji untuk menentukan $\mathrm{KHM}$, baris 7 dan 8 (grup 4) berisi media dan bakteri $(\mathrm{M}+\mathrm{B})$ berfungsi sebagai kontrol positif. Kemudian microplate tersebut dieramkan secara fakultatif anaerob dalam eksikator pada suhu 37C Selama 48 jam, penentuan KHM berdasarkan pada kekeruhan biakan dan pembacaan hasil inkubasi dengan microplate reader. Nilai absorban digunakan untuk menentukan nilai KHM dengan menggunakan rumus : $\{(\mathrm{M}+\mathrm{S}+\mathrm{B})-(\mathrm{M}+\mathrm{B}) /(\mathrm{M}+\mathrm{B})-(\mathrm{M})\}$ $x 100 \%$. Nilai konsentrasi hambat minimum adalah konsentrasi terkecil yang memberikan hasil negatif.

Konsentrasi bunuh minimum adalah konsentrasi terkecil dari ekstrak cathecin teh putih yang masih mampu membunuh $\mathrm{S}$. sanguinis yang ditandai dengan tidak adanya koloni bakteri pada Lempeng Agar Darah (LAD) setelah kontak dengan ekstrak cathecin teh putih. Untuk menentukan KBM dari setiap sumur mikroplate pada baris 5 dan 6 yang tidak keruh diambil satu oese suspensi biakan S. sanguinis dan ditanam pada LAD steril lalu dieramkan lagi dalam eksikator dengan suhu 37C selama 48 jam. Setelah pengeraman 48 jam akan terlihat koloni bakteri yang

Tabel 1 Hasil nilai absorban hemodigesti pada LAD yang menunjukkan adanya pertumbuhan bakteri dan LAD yang tetap steril atau tidak terdapat koloni yang menunjukkan tidak adanya bakteri. KBM ditentukan dengan konsentrasi terkecil yang menunjukkan tidak ada pertumbuhan $\mathrm{S}$. sanguinis.

\section{HASIL PENELITIAN}

Pengamatan pertumbuhan bakteri pada metode mikrodilusi dapat menggunakan larutan indikator, pengamatan kekeruhan, atau dengan pembacaan absorban menggunakan plate reader. Pengamatan kekeruhan ekstrak cathechin teh putih pada penelitian secara visual terhadap microplate setelah diinkubasi selama 48 jam pada suhu 370c tidak dapat dilakukan karena sampel ekstrak cathechin teh putih berwarna pekat dan keruh sehingga sulit untuk menentukan perbedaan kekeruhan antara grup uji dan grup kontrol. Nilai konsentrasi hambat minimum ditentukan dengan cara pembacaan hasil kekeruhan pada microplate dengan plate reader. Hasil pembacaan plate reader dapat dilihat pada tabel 1.

\begin{tabular}{|c|c|c|c|c|c|c|c|c|c|c|c|c|}
\hline & $\mathrm{A}$ & B & $\mathrm{C}$ & D & $E$ & $\mathrm{~F}$ & $\mathrm{G}$ & $\mathrm{H}$ & I & $\mathrm{J}$ & $\mathrm{K}$ & $\mathrm{L}$ \\
\hline 1 & 0,869 & 0,514 & 0,314 & 0,172 & 0,101 & 0,077 & 0,057 & 0,054 & 0,053 & 0,047 & 0,049 & 0,046 \\
\hline 2 & 0,839 & 0,456 & 0,257 & 0,125 & 0,084 & 0,061 & 0,05 & 0,049 & 0,047 & 0,046 & 0,046 & 0,048 \\
\hline 3 & 0,056 & 0,139 & 0,043 & 0,041 & 0,041 & 0,049 & 0,043 & 0,044 & 0,042 & 0,042 & 0,043 & 0,044 \\
\hline 4 & 0,083 & 0,05 & 0,042 & 0,042 & 0,042 & 0,062 & 0,049 & 0,045 & 0,044 & 0,043 & 0,043 & 0,043 \\
\hline 5 & 0,936 & 0,481 & 0,24 & 0,138 & 0,113 & 0,118 & 0,109 & 0,106 & 0,099 & 0,09 & 0,104 & 0,126 \\
\hline 6 & 0,844 & 0,449 & 0,237 & 0,13 & 0,115 & 0,098 & 0,094 & 0,097 & 0,093 & 0,099 & 0,1 & 0,1 \\
\hline 7 & 0,11 & 0,077 & 0,079 & 0,074 & 0,078 & 0,07 & 0,073 & 0,074 & 0,076 & 0,08 & 0,08 & 0,082 \\
\hline 8 & 0,081 & 0,079 & 0,076 & 0,073 & 0,08 & 0,077 & 0,077 & 0,079 & 0,086 & 0,076 & 0,076 & 0,078 \\
\hline $\mathbf{K}$ & 4000 & 2000 & 1000 & 500 & 250 & 125 & 62,5 & 31,25 & 15,63 & 7,813 & 3,906 & 1,953 \\
\hline $\mathrm{R} 1,2$ & 0,854 & 0,485 & 0,286 & 0,149 & 0,093 & 0,069 & 0,054 & 0,052 & 0,05 & 0,047 & 0,048 & 0,047 \\
\hline R 3,4 & 0,07 & 0,095 & 0,043 & 0,042 & 0,042 & 0,056 & 0,046 & 0,045 & 0,043 & 0,043 & 0,043 & 0,044 \\
\hline R 5,6 & 0,89 & 0,465 & 0,239 & 0,134 & 0,114 & 0,108 & 0,102 & 0,102 & 0,096 & 0,095 & 0,102 & 0,113 \\
\hline R 7,8 & 0,096 & 0,078 & 0,078 & 0,074 & 0,079 & 0,074 & 0,075 & 0,077 & 0,081 & 0,078 & 0,078 & 0,08 \\
\hline \multicolumn{12}{|c|}{ Keterangan: } & \\
\hline $\mathrm{K}: \mathrm{ko}$ & & & & & & & & & & & & \\
\hline
\end{tabular}


Tabel 2. Nilai persentase kematian bakteri

\begin{tabular}{ccccccccccccc}
\hline & $\mathrm{A}$ & $\mathrm{B}$ & $\mathrm{C}$ & $\mathrm{D}$ & $\mathrm{E}$ & $\mathrm{F}$ & $\mathrm{G}$ & $\mathrm{H}$ & $\mathrm{I}$ & $\mathrm{J}$ & $\mathrm{K}$ & $\mathrm{L}$ \\
$\mathrm{K}$ & 4000 & 2000 & 1000 & $\mathbf{5 0 0}$ & 250 & 125 & 62,5 & 31,25 & 15,63 & 7,813 & 3,906 & 1,953 \\
$\% \mathrm{~KB}$ & 138,5 & 117,6 & $-134,3$ & $\mathbf{- 4 6 , 9}$ & 56,8 & 216,7 & 165,5 & 156,3 & 121,1 & 137,1 & 154,3 & 183,3 \\
\hline
\end{tabular}

Tabel 3. Hasil Subkultur pada LAD

Lempeng Agar Darah

Pengulangan 1

Pengulangan 2

\begin{tabular}{ccc}
$4000 \mathrm{ppm}$ & - & - \\
$2000 \mathrm{ppm}$ & - & - \\
$1000 \mathrm{ppm}$ & + & + \\
$5000 \mathrm{ppm}$ & + & + \\
\hline Keterangan: + (ada pertumbuhan bakteri) & & - (tidak ada pertumbuhan bakteri)
\end{tabular}

Nilai absorban pada tabel 1 digunakan pertumbuhan bakteri Streptococcus sanguis pada konsentrasi 500ppm( $0,5 \mathrm{mg} / \mathrm{ml})$ dan $1000 \mathrm{ppm}(1 \mathrm{mg} / \mathrm{ml})$, hasil subkultur pada konsentrasi 2000ppm $(2 \mathrm{mg} / \mathrm{ml})$ dan 4000ppm $(4 \mathrm{mg} / \mathrm{ml})$ tidak memperlihatkan pertumbuhan koloni bakteri Streptococcus sanguis. Hasil subkultur dapat dilihat pada tabel 3.

Konsentrasi bunuh minimum adalah konsentrasi terkecil dari ekstrak cathecin teh putih yang mampu membunuh Streptococcus sanguis yang ditandai dengan tidak adanya koloni bakteri pada lempeng agar darah (LAD) setelah kontak dengan ekstrak cathecin teh putih, dari hasil subkultur disimpulkan konsentrasi bunuh minimum (KBM) ekstrak cathechin teh putih terhadap Streptococcus sanguis berada pada konsentrasi 2000ppm $(2 \mathrm{mg} / \mathrm{ml})$.

baris ke 5 dan 6 ke dalam lempeng agar darah (LAD) yang kemudian di inkubasi selama 48 jam pada suhu 370c, dimulai dari konsentrasi 500ppm sampai 4000ppm.

Hasil subkultur ke dalam lempeng agar darah (LAD) menunjukkan masih terdapat

\section{DISKUSI}

Dari hasil penelitian menunjukkan bahwa ekstrak cathechin teh putih memiliki aktivitas 
antibakteri yang tinggi. Bahan alam dianggap memiliki aktivitas yang kuat jika memiliki KHM antara 0,05 sampai $0,5 \mathrm{mg} / \mathrm{ml}$, aktivitas sedang jika nilai $\mathrm{KHM} 0,6$ sampai $1,5 \mathrm{mg} / \mathrm{ml}$, dan dikatakan memiliki aktivitas yang lemah jika diatas $1,5 \mathrm{mg} / \mathrm{ml}$.

Mekanisme yang menyebabkan penghambatan dalam penghambatan pertumbuhan bakteri Streptococcus sanguis oleh ekstrak cathechin teh putih diduga disebabkan adanya interaksi cathechin yang merupakan kelompok senyawa fenol dengan sel bakteri. Fenol membentuk ikatan dengan protein yang terdapat di dinding sel bakteri melalui proses absorbsi yang melibatkan ikatan hidrogen. Pada kadar rendah terbentuk kompleks protein-fenol dengan ikatan yang lemah dan segera mengalami penguraian, diikuti penetrasi fenol ke dalam sel menyebabkan presipitasi serta denaturasi protein. Pada kadar tinggi fenol menyebabkan koagulasi protein dan lisis membran sel. Fenol juga dapat mengubah permeabilitas membran sel bakteri, sehingga menimbulkan kebocoran konstituen sel yang esensial dan mengakibatkan kematian bakteri. ${ }^{13,14,15}$

Penelitian oleh Sadhegi pada tahun 2011 mendapatkan hasil Nilai KHM dan KBM khlorheksidin terhadap Streptococcus sanguinis pada konsentrasi $0,256 \mathrm{mg} / \mathrm{ml}$ dan $0,512 \mathrm{mg} / \mathrm{ml}^{16}$ Hasil $\mathrm{KHM}$ dan KBM ekstrak cathechin teh putih pada penelitian imi mempunyai konsentrasi yang lebih besar dibandingkan dengan khlorheksidin sehingga dapat disimpulkan khlorheksidin yang merupakan standar emas obat kumur lebih efektif dibandingkan ekstrak cathechin teh putih dalam menghambat Streptococcus sanguinis yang merupakan bakteri pelopor pembentuk plak. Ekstrak cathechin teh putih juga efektif untuk menghambat pertumbuhan
Streptococcus mutans dengan KHM dan KBM sebesar 6 dan $8 \% .^{17}$

Khlorheksidin yang merupakan standar emas obat kumur terbukti efektif dalam mengontrol pertumbuhan bakteri plak termasuk Streptococcus sanguinis, tetapi khlorheksidin dapat menyebabkan efek samping berupa iritasi mukosa, perubahan rasa kecap, pewanaan gigi dan peningkatan pembentukan kalkulus. Ekstrak cathechin teh putih walaupun mempunyai nilai KHM dan KBM pada konsentrasi yang lebih besar dari khlorheksidin tetap mempunyai potensi yang besar untuk dikembangkan menjadi alternatif obat kumur herbal disebabkan memiliki aktivitas anti bakteri yang tinggi ditandai dengan $\mathrm{KHM}$ sebesar $0,5 \mathrm{mg} / \mathrm{ml}$ terhadap Streptococcus sanguinis serta juga efektif untuk menghambat pertumbuhan Streptococcus mutans.

\section{KESIMPULAN}

Ekstrak cathechin teh putih memiliki efek antibakteri. Ekstrak cathechin teh putih mempunyai potensi untuk digunakan sebagai bahan kumur herbal untuk mengontrol pembentukan plak gigi.

\section{DAFTAR PUSTAKA}

1. Angela A. Pencegahan primer pada anak yang beresiko karies tinggi. MKG. Juli-September 2005; 38 (3): 130-34.

2. Genco, RJ., Goldman, HM., Cohen, DW. Contemporary Periodontics. St. Louis: The CV Mosby Company; 1990. 170-82, 361-69.

3. Roth, GI . \& Calmes, R. Oral biology. St. Louis: The CV Mosby Company; 1981. 329-35.

4. Darby, Michele Leonardi. Dental Hygiene Theory and Practice. St. Louis : W. B. Saunders Company; 2003. 258-63

5. Xu, P, Alves JM, Kitten T, Brown A, Chen Z, Ozaki LS, et al. Genome of the opportunistic pathogen streptococcus sanguinis. J Bacteriol. 2007; 189(8): 3166-175

6. Lindhe. Clinical Periodontology and implant 
Dentistry. Oxford : Blackwell Munksgaard; 2003.

7. Suwandi T, Suniarti DF, Prayitno SW. Effect of ethanol extract of Hibiscus sabdariffa L. calyx on Streptococcus sanguinis viability in vitro biofilm based on crystal violet. Journal of Medicinal Plants Research. 2013; 7(33): 2476-482

8. Murray, J. J., Nunn, J. H., Steele, J.G. The Prevention of Oral Disease. New York: Oxford University Press, 2003. 130, 136, 138

9. Sinija, V.R \& Mishra, H.N. Green Tea: Health benefits. Journal of Nutritional \& Enviromental Medicine. 2008;17(4):232-42

10. Unachukwu U.J, Ahmed S, Kavalier A, Lyles J.T, Kennely E.J. White and Green teas (camellia sinensis var sinensis): variation in phenolic, methylxanthine, and antioxidant profiles. Journal of food science. 2010; 75 : 541-48

11. Hilal $Y$, Engelhardt $U$. Characterisation of white tea-comparison to green and black tea. Journal of consumer protection and food safety. 2007;2: 414-21

12. Sharangi A.B. Medicinal and therapeutic potentialities of tea (camellia sinensis L)-A review. Food Research International. 2009; 42: 529-35

13. Handajani J, Regina TC. Pengaruh daya antibakteri ekstrak daun teh segar (camellia sinensis) terhadap Streptococcus alpha. Journal of the Indonesian dental association. 2000;50 (2):14-21

14. Adniana N. Perbedaan efektivitas obat kumur chlorhexidine tanpa alkohol dibandingkan dengan chlorhexidine beralkohol dalam menurunkan kuantitas koloni bakteri rongga mulut. Karya ilmiah Akhir: Universitas Sebelas Maret. 2010.

15. Tsuchiya $H$. Effects of green tea cathechins on membrane fluidity. Pharmacology. 1999; 59: 34-44

16. Sadhegi, R., P. Owila, M.B. Rezvani and F. Taleghani. An in-vitro comparison between anti-microbial activity of nanosilver and chlorhexidine against Streptococcus sanguinis and actinomyces viscosus. J. Islam Dent Assoc. 2011; 23: 225-31

17. Noorhamdani, Endang Y, Setyawan H.P. Ekstrak daun teh putih (camellia sinensis) sebagai antibakteri terhadap Streptococcus mutans secara in Vitro. Karya ilmiah akhir: Universitas Brawijaya. 2013. 